\title{
Examination Essays, Paratext, and Confucian Orthodoxy: Negotiating the Public and Private in Knowledge Authority in Early Seventeenth-Century China
}

\author{
Hang Lin
}

Book production reached the first 'golden age' of Chinese printing in the Song dynasty (96o-1276), but it experienced a falling-off in the following two centuries. ${ }^{1}$ From the second half of the Ming dynasty (1368-1644), particularly during the late sixteenth and early seventeenth centuries, there was another printing boom in central and southern China. A thriving commercial printing trade left its mark on China's cultural landscape during this period, especially on the civil service examination system. As the key institution charged with training and recruiting civil servants from late imperial China to 1905 , the civil service system of $k e j u$ 科舉 ('imperial examination') was known for its emphasis on formalism and conformity to the state-set Confucian orthodoxy centring around the master Zhu Xi 朱喜 (1130-1200). ${ }^{2}$ The examination system, itself an instrument of the imperial state, was aimed at training literary elites with political aspirations through rote learning and ideological indoctrination. Through this system, the Confucian orthodoxy formed a rigid public matrix in

1 I am grateful to Kai Vogelsang and Max J. Fölster for their invaluable inputs on printing and book cultures in late imperial China. The research for this chapter is funded by the Hangzhou Municipal Funding for Humanities and Social Sciences (2019J D 04).

Tsien T.-H., Paper and Printing, in Needham J. (ed.), Science and Civilisation in China, vol. 5, Chemistry and Chemical Technology, part 1 (Cambridge: 1985) 159. On printing during the Song, marked by advanced woodblock printing technologies and moveable types, see Poon M.-S., "Books and Printing in Sung China, 96o-1279" (Ph.D. dissertation, University of Chicago: 1979); Cherniack S., "Book Culture and Textual Transmission in Sung China", Harvard Journal of Asiatic Studies 54.1 (1994) 5-125.

2 See Bol P.K., "This Culture of Ours": Intellectual Transitions in T'ang and Song China (Stanford, CA: 1992); Elman B.A., "Social, Political, and Cultural Reproduction in Civil Examination", Journal of Asian History 50.1 (1991) 7-28. 
which all learned individuals were tightly connected to the imperial government, forming what Benjamin A. Elman calls 'a cultural prison.' ${ }^{3}$

The civil service examination system, however, was far from a public domain in which the state established absolute control over individuals. Despite the state's efforts to access and regulate the minds of examinees through ideological cohesion and indoctrination, there was a number of ways for the literati to resist and even appropriate official ideology. One of the most important tools in this process was printing, especially prints produced by non-official and commercial publishers. Printing developed dramatically in the late sixteenth century and increasingly shaped the minds of the examinees and their practices during the examinations. ${ }^{4}$ However, this development elicits questions regarding the production of these commercial publishers. What did the commercial publishers produce? How did these publishers, and the individuals they represented, gain access to the public and eventually mould the mindset and practices of a larger community? What methods did they employ in order to undermine the imperial court's ideological control over the literati? To what extent did their efforts lead to change in the perception of $s i$ 私 ('private') and gong 公 ('public') in the cultural sphere in late imperial China?

This chapter tackles these questions through an analysis of selected prints dating from the late Ming, especially the dynasty's final decades. By conducting an inquiry into the political and intellectual history of this period, I identify two major types of prints, namely collections of examination essays and privately published commentaries. I also explore how these texts contributed to the changing conception of the public vis-à-vis the private in the literary and intellectual world of seventeenth-century China. Through an investigation of these prints along with the individuals involved in their production and circulation, I demonstrate how a rapid expansion of commercially published prints led to the emergence of an alternative interpretation of the canonical texts. These commercial prints, in particular those related to the imperial examination system, often contested the state orthodoxy, yet they became increasingly popular and eventually challenged Zhu Xi's monopoly as the authority on Confucian canons. As a result, the definition of 'public' was increasingly shaped by the literati rather than the imperial court. Changing the boundary between the public and the private, new varieties of examination books came to play a dominant role in the negotiation of knowledge authority and political

3 Elman B.A., A Cultural History of Civil Examinations in Late Imperial China (Berkeley, CA: 2000) 142 .

4 Lin H., "Intersecting Boundaries: Manuscript, Printing, and Book Culture in Late Ming China", Oriens Extremus 52 (2013) 263-304, here 273. 
conduction. The printing boom in late Ming China played an active role in making a much greater variety of texts accessible to a much broader reading public. Regardless of how these new expositions were actually received, they document that there was not only one way of interpreting the Confucian canon. They eventually expanded the intellectual horizons of the literati. \\ Examinations in Ming China: Official Texts and State Orthodoxy}

Civil service examinations were first adopted by the Tang (618-907) emperors in the seventh century as a way to curb the military aristocracy's excessive power. Starting from the end of the tenth century under the Song court, such examinations became the most important means for the imperial state to recruit its officials. Administered on three levels - prefectural, provincial, and metropolitan (national) - the exams tested men from all over the empire for entry into government service. ${ }^{5}$ Since all exams were arranged according to a common curriculum centring around Confucian canons, the examination system helped to shape a state orthodoxy and a uniform national culture based on Confucianism.

After a gap in the early Yuan dynasty (1271-1368), the examinations were reinstated in 1315 by the Song Neo-Confucian Zhu Xi's commentaries on the Four Books authorised as the official version of the textbooks. ${ }^{6}$ Zhu's interpretation of the Confucian canons was entrenched as state orthodoxy under the reign of Ming emperor Yongle 永樂 (r. 1403-1424). In 1415, Sishu daquan 四書大全 (The Complete Compendium on the Four Books) and Wujing daquan 五經大全 (The Complete Compendium on the Five Classics) were published and distributed to government schools according to imperial order. ${ }^{7}$ As the core

5 For detailed accounts on the examinations in the Tang and Song periods, see Chaffee J.W., The Thorny Gates of Learning in Sung China: A Social History of Examinations (Cambridge: 1985) 196-202; Gernet J., A History of Chinese Civilization, trans. J.R. Foster - C. Hartman, 2nd ed. (Cambridge: 1996 [Paris: 1972]) 257-258, 304-305; Kuhn D., The Age of Confucian Rule: The Song Transformation of China (Cambridge, MA: 2009) 42-43, 120-124.

6 Selected by Zhu Xi, the Four Books include The Great Learning (Daxue 大學), The Doctrine of Mean (Zhongyong 中), The Analects of Confucius (Lunyu 論語), and The Mencius (Mengzi 孟子). On examinations in the Yuan, see Wilson T.A., A Genealogy of the Way: The Construction and Uses of the Confucian Tradition in Late Imperial China (Stanford, CA: 1995) 47-59.

7 The Five Classics refer to The Book of Poetry (Shijing), The Book of History (Shujing), The Book of Rites (Liji), The Book of Changes (Yijing), and The Spring and Autumn Annals (Chunqiu). On the promulgation of the Sishu daquan and Wujing daquan as official texts for examinations in the Ming, see Elman B.A., "The Formation of 'Dao Learning' as Imperial Ideology during 
texts for the preparation of the examinations, these works were to serve as the basis for the study of the Confucian classics and remain in use until the early eighteenth century.

Represented by Zhu's expositions of the canons, the examination system occupied a principal position in the institution that tied the learned elites to the imperial state, creating a particular intellectual community of shared mindsets, i.e. aspiring examinees who lived in all corners of the empire. For the state, the promulgation of Zhu's commentaries as the official interpretation of the Confucian classics was, to a large extent, meant to impose a government-sanctioned reading of the canonical texts. By freezing the meaning of the ancient canons through the administration of examinations, the state drew clear demarcations of the semantic field of the book. By doing so, it incorporated the students into a fixed communication circuit, establishing an orthodox literality. ${ }^{8}$ The examination system thus functioned as a major government institution that sought to reinforce the empire's cultural, social, and political order.

For the examinees, this examination played a crucial role in creating a community of the educated elite who were involved in reproducing the regime's ideological authority. The employment of proper literary strategies that involved both form and content was essential for the examinees as their success hinged on their demonstration of both interpretively new and politically correct understanding of the canon. ${ }^{9}$ By 1630 , the examinations had become extremely competitive: Elman observes that only one out of fifteen candidates who passed the provincial examination could go on to compete on the national level in the following year. ${ }^{10}$ On the one hand, in order for an examinee to distinguish himself among tens of thousands of candidates, candidates were required to demonstrate a superior understanding of the texts through new elaborations within the government-sanctioned domain of the canons. On the other hand, however, the presence of a state orthodoxy meant that their success was dependent on their mastery of official protocol. Only those who conformed to the official interpretation could hope to be rewarded by examination titles and government posts; aberrant readings would be purged from the communication circuit. Those who occasionally floated unorthodox ideas were strictly suppressed as their names were erased from the list of successful

the Early Ming Dynasty", in Hunters T. - Wong B. - Yu P. (eds.), Culture and State in Chinese Society: Conventions, Accommodations, and Critique (Stanford, CA: 1997) 58-82.

8 De Certeau M., The Practice of Everyday Life, trans. S. Rendall (Berkeley, CA: 2011) 171.

9 Chow K.-W., Publishing, Culture, and Power in Early Modern China (Stanford, CA: 2004) 93.

10 Elman B.A., A Cultural History of Civil Examinations 140-143, cited in Brook A., The Troubled Empire: China in the Yuan and Ming Dynasties (Cambridge, MA: 2010) 149. 
candidates, no matter how literarily talented they were. In this way, the state cemented a particular public sphere, to which all learned elites were supposed to abandon their individual ideas and submit themselves.

In order to mould the candidates' practices, the imperial government regularly published official results of provincial and metropolitan examinations known as Huishi lu 會試錄 (Records of the Metropolitan Examination). Initially containing only prefaces and the names of examiners and graduates, in 1385 these records began to include exam questions and a few chengwen 呈文 ('model essays'). These essays were written either by successful candidates, though with significant edits by the examiners, or by the examiners themselves. ${ }^{11}$ In 1585 , edited essays by successful graduates were finally included as models in addition to those written by the examiners. Two years later, the Ministry of Rites, the state organ responsible for organising and monitoring the examinations, was instructed to publish selected metropolitan exam essays from the beginning of the dynasty through the 158 os. ${ }^{12}$ Having been edited by the examiners, all published essays could be trusted to conform to the state's vision as unorthodox styles and ideas were eliminated. In this way, certain official standards could be followed to keep future candidates within the governmentsanctioned public sphere. For the examinees, the anthologies of essays could serve as an excellent aid because they offered convenient answers to possible questions. More importantly, these essays enabled examinees to familiarise themselves with what was deemed acceptable by the state. Parallel to the publication of these model essays, a growing number of collections of essays by graduates, many of them with comments not by the examiners but by professional critics, began to emerge in the book market. In addition to those authored by the top graduates, there was also a notable number of essays by other examinees, many of whom were provincial graduates seeking success in the metropolitan examination. Unlike model essays composed or edited by examiners, these untreated essays opened up a new discursive space for the

\footnotetext{
11 Wang Shizhen 王士禎, Gufuyuting zalu 古夫于亭雜錄 (Random Records of the Old Fuyu Pavilion), in Congshu jicheng xubian 叢書集成續編 (Taipei: 1989) 2: 18b.

12 Sun Chengze 孫承澤, Chunmingmeng yulu 春明夢餘錄 (Supplemented Records of the Dreams of Spring Brightness), in Siku quanshu zhenben 四庫全書珍本, series 6 (Taipei: 1979） 7: 8b-9a; Gu Yanwu 顧炎武, Rizhilu 日知錄 (Record of Daily Knowledge), Huang Rucheng 黃汝成 (ed.), as Rizhilu jishi 日知錄集釋 (Collected Explanations of the Records of Daily Knowledge), Siku beiyao 四庫備要 edition (Taipei: 1965) 16: 10a, 21.
} 
examinees and editors and challenged official judging standards. The authority of the examiners was further eroded when failed candidates started to publish their works. ${ }^{13}$ For example, Zhang Pu 張溥 (1602-1641), the famous leader of Fushe 復社 (the Restoration Society), edited a collection of essays by provincial exam candidates in 1627 . After the metropolitan examination in the following spring, Zhang edited another collection of essays from the provincial examination of 1627 . In his preface to the second collection, Zhang explained that because some essays previously praised by the editors did not find success in the metropolitan examination, while some of the overlooked ones did. ${ }^{14}$ Commercial publishers paid for these essays to be reviewed and printed. Through the privately published collections, the critics and editors functioned as a competing second set of examiners, offering their own judgement that was not necessarily in line with the official version. The growing influence of these critics was soon recognised by the readers. The last decades of the Ming witnessed a drastic increase in commercially produced collections of examination essays. They overshadowed those printed by the government in terms of both quality and quantity, to the point that the literary master Yuan Hongdao 袁宏道 (1568-1610) lamented that it was impossible for the examinees to read them all. ${ }^{15}$

For individuals pursuing examination success, inclusion of their essays in the collections was no longer a private act but public evidence of their literary and intellectual merit. Edited and published by persons not holding degrees or any official posts, these collections were originally only acts of specific individuals and were not expected to be publicly distributed to outsiders, although some of these books were acquired by other readers. Their literary excellence and innovative expositions were once celebrated within a very limited circle. Yet as the fame of some collections became increasingly accepted, the essays finally crossed the boundary that separated private and public. Even if one had not yet passed the examinations and was therefore supposed to be unknown, through these collections he could still succeed in attracting the attention of the readers and by doing so harvest large fame among the literati. Even if one failed at passing the examination, he could still be considered a mingshi 名士 ('famed literatus'), if his essay was selected and published by

\footnotetext{
13 Ye Mengzhu 葉夢珠, Yueshi bian 閱世編 (Collection of Reading the World), in Shanghai zhanggu congshu 上海掌故叢書, vol. 1 (Taipei: 1968) 294.

14 Zhang Pu 張溥, Qiluzhai lunlue 七錄齋論略 (Brief Discussion from the Seven Record Studio) (Taipei: 1977) 2: 24a-25a, 32a.

15 Yuan Hongdao 袁宏道, Sabitang xuji 酒碧堂續集 (Continued Collection of PouringJade), in Siku jinhui shu congkan, vol. 67 (Beijing: 1997-200o) 653 .
} 
renowned editors. ${ }^{16}$ With the help of such collections of essays, their authors were not only blurring the boundaries between private and public, but also creating new means to cross the threshold between them.

For those who failed to make their way into collections by famous editors, it was possible to publish their own essays, as there were numerous private publishers looking for authors. To lend credit and increase sales, the author or the publisher would solicit prefaces or remarks penned by respected critics. Huang Ruheng 黃汝亨 (1558-1626), a graduate of the 1598 metropolitan examination and a senior editor, wrote no fewer than sixty prefaces for examination essay collections, among which twenty-five were published by individual authors. ${ }^{17}$ Fang Yingxiang 方應祥 (1561-1628), whose personal collection was graced by Huang's preface, was himself a well-known critic and had published a variety of examination essays with private publishers. When his friend decided to publish an anthology of his works, he wrote to some of the most famous scholars and critics of his time, including Qian Qianyi 錢謙益 (1582-1664), to solicit prefaces. ${ }^{18}$ Ai Nanying 艾南英 (1583-1646), despite never passing the metropolitan examination, rose to prominence as a critic and wrote almost fifty prefaces for individual collections. Fully aware of the influence that critics could exert on the examination results through commenting on and publishing examination essays, he proudly compared an editor's power to that of the emperor himself. ${ }^{19}$

Ai's sense of pride in individual critics' literary authority was telling. Unlike official model essays handed down by the examiners, the critics' chosen works and their preferences constituted an autonomous forum that existed parallel to the official version of the imperial court. Examinees who had their essays commented on and published prior to their examination were, in essence, doing a trial run: by having the examiners view their works prior to the exams, they acquired a special avenue to influence the examiners and had a better chance to succeed. For the critics, too, their public reputation as competent judges carried symbolic value. Chen Jitai 陳際泰 (1567-1641), for example, was

16 LüMudan chuanqi 綠牡丹傳奇 (Legend of the Green Peony), in Quan Ming chuanqi 全明 傳奇, vol. 89 (Taipei: 1983) 2: 22a.

17 On these prefaces, see Huang Ruheng 黃汝亨, Yulin ji 寓林集 (Collection of Residing in the Woods), in Siku jinhui shu congkan, vol. 7 (Beijing: 1997-2000) ch. 7 .

18 Fang Yingxiang 方應祥, Qinglai ge chuji 青來閣初集 (First Collection of Pavilion of the Coming Verdancy), in Siku jinhui shu congkan, vol. 40 (Beijing: 1997-200o) 5: 2ob-21a.

19 Ai Nanying 艾南英, Tianyongzi ji 天傭子集 (Collection of Tianyongzi [Ai Nanying]) (Taipei: 1980) 3: 28a-29b. 
already an established critic with over thirty prefaces under his belt before he finally passed the metropolitan examination at the age of $68 .{ }^{20}$

From the sixteenth to the seventeenth centuries, as pressure from critics and commercial publishers continued to mount, imperial examiners gradually stepped away from the practice of publishing heavily edited essays or their own works as models. By 1625 , the official collections consisted only of essays by graduates in their original form. ${ }^{21}$ As a result, the authority of the examiners was contested and reduced by the examinees and critics, marking a gradual but fundamental turn in the construction of the public literary sphere. The examiners, as representatives of the cultural orthodoxy and state authority, could no longer exert absolute control over how proper essays should be presented to the general students, and they thus lost the power inherent in creating the ideal public sphere centring on Zhu's interpretations. The examinees and critics, who used to be regarded as specific individuals with their own private and unorthodox expositions, were eventually accepted and established as representatives of the new public sphere. In this way, the threshold between public and private was redefined.

\section{Authority on Commentaries: Zhu Xi vs. Ming Scholars}

In addition to essay collections, commercial publishers and individual critics also adopted new discursive strategies to influence the reading process of learned scholars. Further undermining imperial authority in the intellectual sphere, one of the most important tools at their disposal were paratexts. As first coined by Gerard Genette, the paratext - in the form of preface, postscript, colophon, reading guides, commentaries, and intertextual references - contains a large amount of data about the text's production and its transmission through time and space. Taking the paratext into account thus tremendously enlarges the semantic field of the book and acts as the 'threshold of interpretation'.22 Although often relegated to marginality, these surplus texts and contextual devices, many of which were not produced by the authors themselves, created a space for the textualisation of both historical events and personal

20 For his prefaces, see Chen Jitai 陳際泰, Jiwu ji 已吾集 (Collection of Jiwu [Chen Jitai]) (Taipei: 1977) chap. 2-4.

21 Sun, Chunmingmeng yulu, 41: 8a; Chow, Publishing, 222-223.

22 On Genette's discussion of paratext, see Genette G., Seuils (Paris: 1987). Translated into English as Paratext: Thresholds of Interpretation, trans. J.E. Lewin (Cambridge: 1997). See also Genette G., "Introduction into the Paratext" New Literary History 22.2 (1991) 261-272. 
sentiments. ${ }^{23}$ More than the documentation of the individuals involved in the texts' production and dissemination, paratexts provided a venue for authors, editors, commentators, and publishers to convey their messages to the audience. In this way, paratexts also enhanced the influence of prints on the formation of the reading public and their socio-political practices. ${ }^{24}$ While Genette's examples were from sixteenth- and seventeenth-century France, the traits he identified also apply to the latter half of the Ming.

During the first half of the Ming, aside from a few commentaries written by scholars of the Yuan dynasty, commercial publishers limited themselves to reproducing the official version of Zhu Xi's expositions. From the early sixteenth century, several commentaries by Ming scholars emerged as examinee favourites for the following decades, including Cai Qing's 蔡清 (1453-1508) Sishu mengyin 四書蒙引 (Introduction to the Four Books for Beginners), Chen Chen's 陳琛 (1477-1545) Sishu qianshuo 四書淺說 (Elementary Explanation of the Four Books), and Lin Xiyuan's 林希元 (ca. 148o-ca. 1560) Sishu cunyi 四書存疑 (Questions on the Four Books), but they still adhered closely to Zhu's ideas and there were only minor differences among them. ${ }^{25}$ As the growing competitiveness of the examinations coincided with a general boom in commercial printing, this situation changed drastically in the beginning of the seventeenth century. The overwhelming majority of extant Ming commentaries on the Four Books, especially those with datable prefaces, were printed after the 158 os. $^{26}$ While those espousing Zhu's ideology lost influence, new titles providing different interpretations mushroomed.

The proliferation of new and unorthodox commentaries soon caught the attention of the Ministry of Rites, the agency that was tasked with ensuring the examinees' compliance with Zhu's expositions. Several ministers of rites, such as Shen Li 沈鯉 (1531-1615) and Li Tingji 李廷機 (1542-1616), complained about examination aids produced by commercial publishers and criticised the trend of 'new expositions' that increasingly cited heterodox ideas with Buddhist and Taoist influences. ${ }^{27}$ The Ministry issued a series of warnings to

23 Ciotti G. - Lin H., "Preface" to Ciotti G. - Lin H. (eds.), Tracing Manuscripts in Time and Space through Paratexts (Berlin: 2016) vii-xii, here viii.

24 Genette, Paratext 12.

25 Shen Junping 沈俊平, "Ming zhongwanqi fangke zhiju yongshu de chuban ji chaoye renshi de fanying” 明中晚期坊刻制舉用書的出版及朝野人士的反應 (A Study on Commercially-Printed Examination Aids Published after Mid-Ming and Responses from the Government and the Public towards These Publications), Hanxue yanjiu 漢學研究 27.1 (2009) 145-146.

26 For a list of these titles, see Chow, Publishing 266-268.

27 Zhang Tingyu 張廷玉 etc., Mingshi 明史 (History of the Ming), punctuated and collated edition (Beijing: 1974) 217: 5734; Li Tingji 李廷機, Li Wenjie ji 李文節集 (Collection of Li Wenjie [Li Tingji]) (Taipei: 1970) 4: 8b-9a. 
examiners at the county and provincial levels against accepting interpretations deviating from Zhu's, yet due to a growing demand for examinees and the absence of a rigorous censorship system, the Ming government was unable to stop the increasing publication of unorthodox commentaries. ${ }^{28}$ Ironically, even though Shen and Li were self-professed opponents of such 'new expositions', their names nevertheless appeared, probably falsely attributed, on a number of commercially published commentaries, where they were cited as critics, proofreaders, and even authors. ${ }^{29}$

Most of the commercial printers did not dare completely to ignore the government's warnings. In their efforts to avoid accusations of violating sanctions, authors, editors, and publishers actively employed a variety of tactics, primarily in the form of paratext. Thus, the author of Sishu weiyan 四書微言 (Subtle Words of the Four Books) stated in his preface that the unorthodox expositions were only included so that their mistakes could be pointed out to future examinees. ${ }^{30}$ Others provided commentaries that were at odds with Zhu Xi's but were previously accepted by official examiners. Nevertheless, the commentaries opened up the possibility of disparate interpretations, thus undermining the supposed absolute authority of Zhu's orthodoxy as endorsed by the government.

Many of the commercial commentaries could be identified by a sectional format which divided the printed leaf into two, or sometimes three, registers. First adopted by Jianyang publishers in the Fujian province for the printing of popular novels and dramas, this particular format of shangtu xiawen 上圖下文 ('illustration above and text below') were soon embraced as examination aids. ${ }^{31}$ In these works, the main text of the Four Books and Zhu Xi's commentaries were often placed in the bottom section while the top section was reserved for

28 Unlike the Song and Yuan, the Ming did not have a censorship unit nor a specific licensing system to police publishers. Except for a few special types of publication, including calendars and books on astronomy and divination, publishers were free to print almost anything. See Chow K.-W., "Writing for Success: Printing, Examinations, and Intellectual Change in Late Ming China”, Late Imperial China 17.1 (1996) 120-157, here 135; Brook T., The Chinese State in Ming Society (New York: 2004) 118-119, 134-135.

29 For example, Sishu wenlin guanzhi 四書文林觀止 (Unifying Themes of the Literary World in the Four Books) was, although probably falsely, attributed to Li. Another attribution to $\mathrm{Li}$, Sishu dazhu cankao 四書大注參考 (Reference for the Compendium of Commentaries on the Four Books), lists Shen as one of the proofreaders.

30 Tang Ru'e 唐汝諤, preface to Sishu weiyan 四書微言 (Subtle Words on the Four Books) ca. 1610. Courtesy of Harvard-Yenching Library (collection no. o07904106-X).

31 For a detailed discussion of the two-register format in Jianyang books, see Chia L., Printing for Profit: The Commercial Publishers of Jianyang, Fujian (11th-17th Centuries) (Cambridge, MA: 2002) 39-62. 
the critic's xinyi 新意 ('new ideas') or zhangzhi 章志 ('purports of the chapters and verses'). Many of such added texts expressed ideas different from those of Zhu Xi. To indicate the main ideas of a paragraph or section, publishers used specific markers such as mizhi 秘旨 ('secret thesis'), tiyan 題言 ('main point'), biaozong 表宗 ('highlighting the main idea'), and xinjie 新解 ('new exposition for reference'). The ones that did not use this format could still be identified by explicit or implicit references to the examinations in their preface, title, list of proofreaders, fanli 凡例 ('editorial principles'), or a separate section on writing instructions for writing in the bagu 八股 ('eight-legged') style.

In order to differentiate themselves from the competition and gain an edge in the market, publishers paid special attention to their products' titles. Many commentaries' names contained phrases such as 'new ideas' and zhuyi 主意 ('subjective meanings'). This is the case for Qian Zhaoyang's 錢肇陽 Sishu huijie xinyi 四書會解新意 (New Ideas through Comprehensive Expositions of the Four Books) and Zhu Changchun's 朱長春 Sishu zhuyi xinde jie 四書主意 心得解 (Knowledge Gained in the Meanings of the Four Books), both published in $1613 .{ }^{32}$ In addition, many publishers added fashionable phrases to old titles for publicity purposes. For example, many titles were preceded by phrases like xinke 新刻 ('newly carved') or dingjuan 鼎鏶 ('best carved'). Although many of the works were not actually printed for the first time, they all claimed, with varying degrees of veracity, to carry new ideas. In this way, the commercial printers attempted to differentiate their products from those of their competitors.

Another popular paratextual strategy was to highlight the contributors' qualifications in the volumes' titles. In many publications, official titles such as taishi 太史 ('grand historian'), huiyuan 會元 ('first place at the metropolitan examination') or hanlin 翰林 ('academician') were used to underscore the academic success of the contributors. From the early seventeenth century onwards, however, a growing number of publishers preferred to use unofficial titles such as xiansheng 先生 ('Maestro') and $f u$ 傅 ('Elder'). ${ }^{33}$ Later, as minggong 明公 ('reputable masters') were acclaimed as the arbiters of intellectual achievement and literary taste, the title of the minggong yilun 明公議論 ('discourse of reputable masters') became a mark of quality. The rising popularity of non-official titles at the expense of their official counterparts reflected a growing sense that literary authority was no longer the monopoly of the imperial government.

32 Chow, Publishing 267.

33 See, for example, Tang Binyin 湯賓尹, Xinke Tang taishi nishou kechang tizhi 新刻湯 太史擬授科場題旨 (Newly Carved Emulated Title Thesis on Examinations by the Grand Historian Tang). Courtesy of Naikaku bunko (Collection no. kan 8572). 
The said monopoly was further weakened by the inclusion of nonConfucians as contributors. In the anthology of examination essays written by Zhuo Fazhi 卓發之 (fl. 163os), an astonishing number of 128 persons were listed as proofreaders, including eight women and eighteen Buddhists. ${ }^{34}$ The monk Hanshan Deqing 㮩山德清 (1546-1623) published his commentaries on Daxue 大學 (The Great Learning) and Zhongyong 中庸 (The Doctrine of the Mean), two of the Four Books, in 1617. A decade later, these commentaries were reprinted by a private publisher who appended a 38-page section on how to prepare for the examinations. ${ }^{35}$ With this paratext, the publisher repackaged the commentary by Hanshan Deqing into a public product and surreptitiously contributed to subverting the official school of $\mathrm{Zhu} \mathrm{Xi}$, further blurring the already porous demarcation between Buddhist heterodoxy and Confucian orthodoxy.

During the last five decades of the Ming, as a combined result of a boom in commercial printing and the rapid growth of privately edited examination aids, almost all examinees had a degree of access to commercially printed essays and commentaries. In order to distinguish oneself and catch the examiner's eye, a growing number of the literati began to form study groups and literary societies. ${ }^{36}$ Although such organisations could be traced back to the late Yuan years, their previous incarnations were relatively small in size. Moreover, they consisted mostly of government officials whose literary reputation was secondary to their political positions. Starting in the reign of the Wanli Emperor (r. 1573-1620), however, examinees and professional literati outside the political circle greeted the emergence of many new literary societies with great enthusiasm.

Empowered by a booming printing industry, members of these study groups and literary societies took advantage of their circles' organisational power and literary reputation to enhance their exam prospects. In addition to publishing essays and commentaries under their individual names, examinees of the

34 Zhuo Fazhi 卓發之, Luliji 漉篗集 (Collection of Wattle Fence), in Sikujinhui shu congkan, vol. 107 (Beijing: 1997-200o) 295-296.

35 Hanshan Deqing 㪚山德清, Zhongyong zhizhi 中庸直指 (Direct Points to the Book of Mean), in Xiao Tianshi 蕭天石 (ed.), Zhongguo zixue mingzhu jicheng 中國子學名著集 成, chubian, Rujia zibu, vol. 16 (Taipei: 1978).

36 Wang Long 王龍, Zhongguo yuedu tongshi: Mingdai juan 中國閱讀通史: 明代卷 (A General History of Reading in China: The Ming Dynasty) (Hefei: 2017) 403. 
same group or society also began to publish collections of their works to present their communal identity to the book market. It was common for members of the same society to appear as coeditors, proofreaders, or authors of prefaces and commentaries. Many members worked closely with commercial publishers and some even ventured personally into publishing. Wen Qixiang 聞啟祥 (fl. 1610s), for instance, was a leader of Dushushe 讀書社 (the Study Society) in Hangzhou as well as the owner of the society's publishing house Dushufang 讀書 坊, which printed at least sixteen works. ${ }^{37} \mathrm{Gu}$ Menglin 顧夢麟 (1585-1653), a famous critic and one of the founders of Yingshe 應社 (the Response Society) in Suzhou, published the collected works of the society, Sishu shuoyue 四書説約 (Concise Exposition on the Four Books) and Shijing shuoyue 詩經説約 (Concise Exposition on the Book of Poetry), via his private press Zhilianju 織策居. ${ }^{38}$ Thanks to a thriving printing industry, these books were sold inexpensively throughout the empire. In this way, commercial publishing enabled the literati to obtain a national reputation and a degree of publicity that reached beyond their private meetings in local communities.

Not only did examination essay books create an opportunity for individuals and literary societies to transform what was once individual and private into something communal and public, but they also turned the conventional private-public dichotomy on its head when it came to contemporary political issues. Many of the commentaries published during the Wanli period were particularly revealing of the latter development. The Wanli Emperor, who deliberately neglected nearly all his political duties and dispatched eunuchs to major cities to collect extra tax revenue for himself, was widely criticised for his apathy and inaction. ${ }^{39}$ His reign saw a growing number of commentaries that discussed a ruler's proper attitude towards wealth. Focusing on the final section of The Great Learning, which explained the importance of a ruler's moral cultivation in ping tianxia 平天下 ('pacifying the realm'), these commentaries put increasing emphasis on how proper distribution of wealth would help with maintaining the imperial order. Whereas Zhu Xi's expositions focused on how a ruler's moral cultivation and conduct could win the support of his people and manage the government, many Wanli-era commentaries shifted their attention to the emperor's role in mismanaging the country's financial resources.

For some of the works published by Dushufang, see Du Xinfu 杜信孚, Mingdai banke zonglu 明代版刻綜錄 (A Comprehensive Catalogue of Ming Woodblock Printing) (Yangzhou: 1983) 8: 9b-10a.

38 Du, Mingdai banke zonglu 7: 21b-22a.

39 Huang R., 1587, A Year of No Significance: The Ming Dynasty in Decline (New Haven, CT: 1981) 13-14, 61-63; Brook, The Troubled Empire 119-12o. 
A commentary by Tang Binyin 湯賓尹 (b. 1568), for example, explicitly criticised the ruler's attitude towards wealth and its consequence, complaining that the emperor (i.e. Wanli) set his mind on making profit and competed with his subjects for wealth. Under his influence, everybody struggled for wealth instead of justice. ${ }^{40}$ Similar criticism of the emperor appears in another commentary by Yao Shunmu 姚舜牧 (1543-1627), who directly accused the emperor of taking advantage of his subjects and indulging himself in the pursuit of his own profit. It became even worse when he occupied the throne and wielded absolute power. ${ }^{41}$

No examinee reading such remarks would mistake them for mere scholarly exposition. Alluding to passages from the Confucian canon, the commentaries reversed the conventional connection of imperial interests with the public and those of the subjects with the private. For the commentators and their readers, proper distribution of wealth among the subjects was for the good of the public, whereas monopolising profit by the emperor meant following his own interests and thus harming the cause of public justice.

\section{Concluding Remarks}

After six decades that witnessed the gradual decline of the state orthodoxy, new expositions finally mounted an open challenge to Zhu Xi's school of thought. This development took place during the last years of the Ming, when literary societies continued to grow and began to exert their influence on the outcome of the examinations through control of public opinion over the judging criteria. This was most clearly visible in the case of Zhang Zilie 張自 烈 (1597-1673), who, in 1638, published his own commentaries on the Four Books. Quoting freely from a wide range of texts, some of them falsified, Zhang abandoned Zhu's division of the chapters into Classics and commentary, and he also eliminated Zhu's supplementary section on gewu 格物 (the investigation of things). Although his commentaries still only represented his personal opinion, what set Zhang apart from his predecessors was the organisational support at his disposal. As the leading figure of the Restoration Society, the largest and most influential literati circle of the time, he convinced his friends

40 Tang Binyin 湯賓尹, Shui'an Sishu mai 睡庵四書脈 (Shui'an [Tang Binyin] Pulse of the Four Books) 2ob-21a, quoted from Kin Bunkyō, 金文京, “Tō, Hin’i to Minmatsu no shōgyō shuppan”, 湯賓尹と明末の商業出版 (“Tang Binyin and the Commercial Publishing in the Late Ming"), in Arai Ken 荒井健 (ed.), Chūka bunjin no seikatsu 中華文人の生活 (Life of Chinese Literati) (Tokyo: 1994) 354.

41 Chow, Publishing 184. 
and many officials to petition for his version to replace Zhu Xi's as the state orthodoxy. From 1638 to 1644, Zhang's supporters submitted three petitions to the imperial court, although the Ming dynasty ended before they could be officially submitted to the emperor for review.

According to the records, all three rounds of petitions were termed gongjie 公揭 ('public proclamations'). Ironically, however, gong 公 ('public') here referred to the examinees and critics, not to the imperial government. To a great extent, the inverted definition of the public and the private reflected the gradual process that was characterised by dissociating the imperial state from the term 'public'. In this way, the terms 'public' and 'private' also acquired new semantic implications. The orthodoxy of Zhu Xi's interpretations of the canons, patronised by state authority, was supposed to be publicly embraced by all students in the empire, while expositions different to Zhu's were heretic and needed to be suppressed. In this way, the imperial state represented the public opinion. But when large-scale petitions advocating interpretations that directly diverged from Zhu's were organised by literati across the entire empire, what the state once stood for suddenly became heretic itself. The state orthodoxy, once established as public and authoritative, was now pushed to the side of private and unofficial. The opinions of individual literati, in contrast, transcended the boundaries to enter the sphere of public and official.

The expansion of private commercial printing dislodged the state from its central position in the publishing industry; at the same time, it enabled individuals to achieve an unprecedented degree of autonomy that eventually rivalled state orthodoxy. Through printing, ideas of private individuals and intellectual groups acquired a platform to reach a much larger readership and became accepted by larger communities, thus transforming the private into the public. The state orthodoxy represented by Zhu Xi, by contrast, was consistently challenged and eventually subverted and relegated to the sphere of the private.

\section{Bibliography}

Ai Nanying 艾南英, Tianyongzi ji 天傭子集 (Collection of Tianyongzi [Ai Nanying]) (Taipei: 1980).

Bol P.K., "This Culture of Ours": Intellectual Transitions in T'ang and Song China (Stanford, CA: 1992).

Brook T., The Chinese State in Ming Society (New York: 2004).

Brook T., The Troubled Empire: China in the Yuan and Ming Dynasties (Cambridge, MA: 2010). 
Chaffee J.W., The Thorny Gates of Learning in Sung China: A Social History of Examinations (Cambridge: 1985).

Chen Jitai 陳際泰, Jiwu ji 已吾集 (Collection ofJiwu [Chen Jitai]) (Taipei: 1977).

Cherniack, S., "Book Culture and Textual Transmission in Sung China", Harvard Journal of Asiatic Studies 54.1 (1994) 5-125.

Chia L., Printing for Profit: The Commercial Publishers of Jianyang, Fujian (11th-17th Centuries) (Cambridge, MA: 2002).

Chow K.-W., "Writing for Success: Printing, Examinations, and Intellectual Change in Late Ming China", Late Imperial China 17.1 (1996) 120-157.

Chow K.-W., Publishing, Culture, and Power in Early Modern China (Stanford, CA: 2004).

Ciotti G. - Lin H. (eds.), Tracing Manuscripts in Time and Space through Paratexts (Berlin: 2016).

de Certeau M., The Practice of Everyday Life, trans. S. Rendall (Berkeley, CA: 2011).

Du Xinfu 杜信孚, Mingdai banke zonglu 明代版刻綜錄 (A Comprehensive Catalogue of Ming Woodblock Printing) (Yangzhou: 1983).

Elman B.A., "Social, Political, and Cultural Reproduction in Civil Examination", Journal of Asian History 50.1 (1991) 7-28.

Elman B.A., "The Formation of 'Dao Learning' as Imperial Ideology during the Early Ming Dynasty", in Hunters T. - Wong B. - Yu P. (eds.), Culture and State in Chinese Society: Conventions, Accommodations, and Critique (Stanford, CA: 1997) 58-82.

Elman B.A., A Cultural History of Civil Examinations in Late Imperial China (Berkeley, CA: 2000).

Fang Yingxiang 方應祥, Qinglai ge chuji 青來閣初集 (First Collection of Pavilion of the Coming Verdancy), in Siku jinhui shu congkan 四庫禁毀書叢刊, vol. 40 (Beijing: 1997-2000).

Genette G., Seuils (Paris: 1987).

Genette G., "Introduction into the Paratext", New Literary History 22.2 (1991) 261-272.

Genette G., Paratext: Thresholds of Interpretation, trans. J.E. Lewin (Cambridge: 1997).

Gernet J., A History of Chinese Civilization, and ed., trans. J.R. Foster - C. Hartman (Cambridge: 1996 [Paris: 1972]).

Gu Yanwu 顧炎武, Rizhilu 日知錄 (Record of Daily Knowledge), Huang Rucheng 黃汝 成 (ed.), as Rizhilu jishi 日知錄集釋 (Collected Explanations of the Records of Daily Knowledge), Siku beiyao 四庫備要 edition (Taipei: 1965).

Hanshan Deqing 懸山德清, Zhongyong zhizhi 中庸直指 (Direct Points to the Book of Mean), in Xiao Tianshi 蕭天石 (ed.), Zhongguo zixue mingzhu jicheng 中國子學名 著集成, chubian, Rujia zibu, vol. 16 (Taipei: 1978).

Huang R. 1587, A Year of No Significance: The Ming Dynasty in Decline (New Haven, CT: 1981).

Huang Ruheng 黃汝亨, Yulin ji 寓林集 (Collection of Residing in the Woods), in Siku jinhui shu congkan, vol. 7 (Beijing: 1997-2000). 
Kin Bunkyō 金文京, “Tō, Hin’i to Minmatsu no shōgyō shuppan”, 湯賓尹と明末の商業 出版 (“Tang Binyin and the Commercial Publishing in the Late Ming”), in Arai Ken 荒井健 (ed.), Chūka bunjin no seikatsu 中華文人の生活 (Life of Chinese Literati) (Tokyo: 1994) 339-383.

Kuhn D., The Age of Confucian Rule: The Song Transformation of China (Cambridge, MA: 2009).

Li Tingji 李廷機, Li Wenjie ji 李文節集 (Collection of Li Wenjie [Li Tingji]) (Taipei: 1970).

Lin H., "Intersecting Boundaries: Manuscript, Printing, and Book Culture in Late Ming China", Oriens Extremus 52 (2013) 263-303.

Lü Mudan chuanqi 綠牡丹傳奇 (Legend of the Green Peony), in Quan Ming chuanqi 全 明傳奇 (Taipei: 1983).

Poon M.-S., "Books and Printing in Sung China, 96o-1279" (Ph.D. dissertation, University of Chicago: 1979).

Shen Junping 沈俊平, "Ming zhongwanqi fangke zhiju yongshu de chuban ji chaoye renshi de fanying” 明中晚期坊刻制舉用書的出版及朝野人士的反應 (“A Study on Commercially-Printed Examination Aids Published after Mid-Ming and Responses from the Government and the Public towards These Publications"), Hanxue yanjiu 漢學研究 27.1 (2009) 141-176.

Sun Chengze 孫承澤, Chunmingmeng yulu 春明夢餘錄 (Supplemented Records of the Dreams of Spring Brightness), in Siku quanshu zhenben 四庫全書珍本, series 6 (Taipei: 1979).

Tang Binyin 湯賓尹, Xinke Tang taishi nishou kechang tizhi 新刻湯太史擬授科場題旨 (Newly Carved Emulated Title Thesis on Examinations by the Grand Historian Tang). Courtesy of Naikaku bunko (Collection no. kan 8572).

Tang Ru'e 唐汝諤, Sishu weiyan 四書微言 (Subtle Words on the Four Books), ca. 1610. Courtesy of Harvard-Yenching Library (collection no. oo7904106-X).

Tsien T.-H., Paper and Printing, in Needham, J. (ed.), Science and Civilisation in China, vol. 5, Chemistry and Chemical Technology, part 1 (Cambridge: 1985).

Wang Long 王龍, Zhongguo yuedu tongshi: Mingdai juan 中國閱讀通史: 明代卷 (A General History of Reading in China: The Ming Dynasty) (Hefei: 2017).

Wang Shizhen 王士禎, Gufuyuting zalu 古夫于亭雜錄 (Random Records of the Old Fuyu Pavilion), in Congshujicheng xubian 叢書集成續編 (Taipei: 1989).

Wilson T.A., A Genealogy of the Way: The Construction and Uses of the Confucian Tradition in Late Imperial China (Stanford, CA: 1995).

Ye Mengzhu 葉夢珠, Yueshi bian 閱世編 (Collection of Reading the World), in Shanghai zhanggu congshu 上海掌故叢書, vol. 1 (Taipei: 1968).

Yuan Hongdao 袁宏道, Sabitang xuji 酒碧堂續集 (Continued Collection of Pouring Jade), in Siku jinhui shu congkan (Beijing: 1997-200o).

Zhang Pu 張溥, Qiluzhai lunlue 七錄齋論略 (Brief Discussion from the Seven Record Studio) (Taipei: 1977). 
Zhang Tingyu 張廷玉 etc., Mingshi 明史 (History of the Ming), punctuated and collated edition (Beijing: 1974).

Zhang Zilie 張自烈, Sishu daquan bian 四書大全辨 (Distinguishing the Complete Compendium of the Four Books), in Siku quanshu cunmu congshu 四庫全書存目叢 書, Jingbu, vol. 169 (Ji'nan: 1999).

Zhuo Fazhi 卓發之, Luli ji 漉篗集 (Collection of Wattle Fence), in Siku jinhui shu congkan, vol. 107 (Beijing: 1997-2000). 